\title{
Pencegahan dan Pengendalian Infeksi Silang pada Tindakan Ekstraksi Gigi di Poliklinik Gigi Rumah Sakit Pancaran Kasih Manado
}

\author{
Moh. Fahmi M. Mokodompit \\ Vonny N. S. Wowor \\ Christy N. Mintjelungan
}

\author{
Program Studi Pendidikan Dokter Gigi Fakultas Kedokteran \\ Universitas Sam Ratulangi Manado \\ Email: fahmimoko@gmail.com
}

\begin{abstract}
One of the high-risk actions in dentistry that can cause cross-infection is tooth extraction because its direct contact with blood, saliva, and critical instrument. This study was aimed to determine the prevention and control of cross infection in dental extractions at the Dentistry Clilnic of Rumah Sakit Pancaran Kasih Manado. This was a descriptive observational study with a cross sectional design. There were 35 subjects in this study obtained by using purposive sampling method. Data were obtained by using a checklist. The results showed that the prevention and control of cross- infection before dental extraction achieved 46,07\%; during dental extraction 59.92\%; and after dental extraction $23,81 \%$. The mean achievement for dental extraction was $60.59 \%$. It is concluded that the prevention and control of cross-infection in dental extraction at the Dentistry Clinic of Rumah Sakit Pancaran Kasih Manado was below maximum level.
\end{abstract}

Keywords: prevention and control of cross-infection, tooth extraction

\begin{abstract}
Abstrak: Salah satu tindakan medis di bidang kedokteran gigi yang mempunyai risiko tinggi terjadinya infeksi silang ialah tindakan ekstraksi gigi karena pada saat pelaksanaannya banyak berkontak dengan darah, saliva, dan instrumen berkategori kritis. Penelitian ini bertujuan untuk mengetahui gambaran tindakan pencegahan dan pengendalian infeksi pada tindakan ekstraksi gigi di Poliklinik Gigi Rumah Sakit Pancaran Kasih Manado. Jenis penelitian ialah deskriptif observasional dengan desain potong lintang. Jumlah subyek sebanyak 35 pasien, diperoleh menggunakan metode purposive sampling. Data penelitian diperoleh dengan menggunakan lembar checklist. Hasil penelitian menunjukkan bahwa pencegahan dan pengendalian infeksi silang sebelum tindakan ekstraksi gigi sebesar 46,07\%; selama tindakan sebesar $59,92 \%$; dan setelah tindakan sebesar $23,81 \%$. Hasil rerata keseluruhan tindakan ekstraksi gigi dilakukan sebesar 60,59\%. Simpulan penelitian ini ialah tindakan ekstraksi gigi di Poli Gigi Rumah Sakit Pancaran Kasih Manado belum maksimal.
\end{abstract}

Kata kunci: pencegahan dan pengendalian infeksi, tindakan ekstraksi gigi

Penyebaran penyakit menular telah meningkatkan kekhawatiran masyarakat maupun petugas kesehatan dalam beberapa dekade terakhir akibat munculnya infeksi mematikan seperti infeksi Human Immunodeficiency Virus (HIV), wabah Severe Acute Respiratory Syndrome (SARS) pada tahun 2003, dan ancaman virus H5N1 (flu burung) dan H1N1 (flu babi). ${ }^{1}$ Penyakit menular dengan prevalensi tertinggi di Indonesia menurut Riset Kesehatan Dasar (Riskesdas 2013) merupakan infeksi saluran pernapasan akut (ISPA), tuberkulosis, hepatitis, selain itu infeksi virus HIV setiap tahunnya semakin meningkat. ${ }^{2}$ Penyakit-penyakit tersebut berisiko tinggi tertular saat pelayanan kesehatan gigi dan mulut baik kepada pasien atau dokter gigi 
selaku operator yang melakukan tindakan pelayanan kesehatan gigi dan mulut. ${ }^{2}$

Seorang dokter gigi berisiko untuk terkena infeksi dan dapat pula menularkan infeksi dari pasien ke pasien lainnya yang dikenal sebagai nama infeksi silang. Menurut Kementerian Kesehatan tahun 2012, infeksi silang dapat terjadi di tempat pelayanan kesehatan gigi melalui empat cara, yaitu pasien ke tenaga pelayanan kesehatan gigi, tenaga pelayanan kesehatan gigi ke pasien, pasien ke pasien, dan tempat pelayanan kesehatan gigi ke komunitas masyarakat. ${ }^{3}$ Dokter gigi dalam melakukan tindakan perawatan berkontak dengan saliva (air liur) dan darah. Saliva dan darah merupakan perantara penularan infeksi sehingga tindakan dalam praktek dokter gigi beresiko tinggi tertular infeksi. Salah satu tindakan di bidang kedokteran gigi dengan resiko tertular infeksi yang tinggi yaitu tindakan ekstraksi gigi.

Ekstraksi gigi adalah proses pencabutan gigi dari dalam soket dan tulang alveolar. Tindakan ekstraksi gigi berisiko tinggi dalam penularan infeksi silang dikarenakan tindakan ini mengakibatkan terjadi pendarahan dalam mulut pasien; selain itu juga menggunakan alat-alat dan instrumen berkategori kritis. Profil kesehatan Kabupaten/Kota Sulawesi Utara tahun 2017 menunjukkan terdapat 8.012 tindakan ekstraksi gigi yang dilakukan sepanjang tahun 2016 di seluruh kabupaten/ kota di Sulawesi Utara. ${ }^{4}$ Angka-angka ini menunjukkan bahwa tindakan ekstraksi gigi merupakan tindakan yang banyak dilakukan sehingga perlu kewaspadaan lebih akan risiko terjadinya infeksi silang pada tindakan ini.

Di rumah sakit, infeksi merupakan masalah yang cukup besar pada pelayanan kesehatan di berbagai belahan dunia dan merupakan risiko terhadap sistem pelayanan kesehatan rumah sakit itu sendiri. Diperkirakan kurang lebih 20-40\% dari kejadian infeksi rumah sakit ialah akibat infeksi silang (cross infection) dari petugas kesehatan yang melakukan pelayanan kesehatan. ${ }^{5}$ Di Indonesia sendiri, suatu bentuk infeksi silang yang banyak terjadi ialah infeksi nosokomial dengan besaran mencapai $15,74 \%$, jauh di atas negara maju yang hanya mencapai angka 4,8-15,5\%. Infeksi nosokomial adalah suatu infeksi yang berasal atau terjadi di rumah sakit. ${ }^{6}$ Terdapat risiko tinggi bagi dokter gigi untuk terkena infeksi silang pada saat melakukan tindakan ektraksi gigi di poliklinik gigi di rumah sakit.

Berdasarkan uraian tersebut, penulis tertarik melakukan penelitian mengenai pencegahan dan pengendalian infeksi silang pada tindakan ekstraksi gigi di Poliklinik Gigi Rumah Sakit Pancaran Kasih Manado. Penentuan lokasi penelitian didasarkan atas pertimbangan lokasi yang mudah dijangkau. Selain itu, hasil survei awal mendapatkan banyak pasien yang dilakukan tindakan ekstraksi gigi di poliklinik gigi rumah sakit ini yang dapat membantu proses penelitian ini.

\section{METODE PENELITIAN}

Jenis penelitian ini ialah deskriptif observasional dengan desain potong lintang. Penelitian dilaksanakan di Poliklinik Gigi Rumah Sakit Pancaran Kasih Manado pada bulan April 2019. Populasi penelitian ialah seluruh tindakan ekstraksi gigi yang dilakukan di Poliklinik Gigi Rumah Sakit Pancaran Kasih Manado. Jumlah subyek penelitian sebanyak 35 orang operator yang diperoleh dengan teknik purposive sampling.

Peneliti melakukan observasi pada operator dimulai dari sebelum tindakan, selama tindakan, dan setelah tindakan ekstraksi gigi dengan menggunakan lembar checklist. Data yang diperoleh diolah secara manual dan disajikan berdasarkan distribusi frekuensi dalam bentuk tabel.

\section{HASIL PENELITIAN}

Hasil penelitian tentang tindakan pencegahan dan pengendalian infeksi silang sebelum ekstraksi gigi terdiri atas tindakan desinfeksi area kerja operator, perlindungan pribadi operator, dan asisten operator.

Distribusi frekuensi tindakan desinfeksi lingkungan kerja operator sebelum 
tindakan ekstraksi gigi terdiri dari tindakan desinfeksi pada pegangan lampu, tombol dental unit, sandaran kepala, tempat duduk, dan meja instrumen. Tabel 1 menunjukkan bahwa tindakan desinfeksi lingkungan kerja operator sebelum tindakan ekstraksi gigi dilakukan pada sebesar $31,43 \%$ responden, sedangkan $68,57 \%$ responden tidak melakukannya.

Distribusi frekuensi perlindungan pribadi operator sebelum tindakan ekstraksi gigi terdiri dari: telah melakukan vaksin hepatitis $\mathrm{B}$, menggunakan masker, mencuci tangan, memakai sarung tangan bedah steril, memakai kacamata pelindung, memakai baju kerja, dan memakai sepatu tertutup. Tabel 2 menunjukkan tindakan perlindungan pribadi operator dilakukan pada sebesar $64,64 \%$ responden, sedangkan $35,35 \%$ responden tidak melakukannya.

Distribusi frekuensi perlindungan pribadi asisten operator sebelum tindakan ekstraksi gigi terdiri dari: telah melakukan vaksin hepatitis $\mathrm{B}$, menggunakan masker, mencuci tangan, memakai sarung tangan bedah steril, memakai kacamata pelindung, memakai baju kerja dan memakai sepatu tertutup. Tabel 3 menunjukkan 42,14\% responden melakukan tindakan perlindungan pribadi sedangkan $57,86 \%$ responden tidak melakukannya.

Distribusi frekuensi tindakan pencegahan dan pengendalian infeksi silang selama tindakan ekstraksi gigi terdiri dari pasien berkumur dengan larutan antiseptik, pengolesan desinfektan sebelum insersi jarum suntik, menutup jarum suntik setelah tindakan anastesi, menutup jarum suntik dengan teknik satu tangan, meletakkan instrumen tajam pada tempat yang aman dan tangan operator tidak menyentuh lingkungan kerja yang tidak steril. Tabel 4 menunjukkan 46,07\% responden melakukan tindakan pencegahan dan pengendalian infeksi silang sebelum tindakan ekstraksi gigi, sedangkan 53,93\% responden tidak melakukannya.

Tabel 1. Tindakan desinfeksi lingkungan kerja operator sebelum tindakan ekstraksi gigi

\begin{tabular}{lcccccc}
\cline { 1 - 1 } \multicolumn{1}{c}{ Tindakan desinfeksi } & \multicolumn{2}{c}{ Ya } & Tidak & \multicolumn{2}{c}{ Total } & \\
lingkungan kerja operator & $\mathrm{n}$ & $\%$ & $\mathrm{n}$ & $\%$ & $\mathrm{n}$ & $\%$ \\
\hline Pegangan lampu & 11 & 31,43 & 24 & 68,57 & 35 & 100,0 \\
Tombol dental unit & 11 & 31,43 & 24 & 68,57 & 35 & 100,0 \\
Sandaran kepala & 11 & 31,43 & 24 & 68,57 & 35 & 100,0 \\
Tempat duduk & 11 & 31,43 & 24 & 68,57 & 35 & 100,0 \\
Meja instrumen & 11 & 31,43 & 24 & 68,57 & 35 & 100,0 \\
Rerata & & 31,43 & & 68,57 & & 100,0 \\
\hline
\end{tabular}

Tabel 2. Perlindungan pribadi operator sebelum tindakan ekstraksi gigi

\begin{tabular}{|c|c|c|c|c|c|c|}
\hline \multirow{2}{*}{ Perlindungan pribadi } & \multicolumn{2}{|c|}{ Ya } & \multicolumn{2}{|c|}{ Tidak } & \multicolumn{2}{|c|}{ Total } \\
\hline & $\mathrm{n}$ & $\%$ & $\mathrm{n}$ & $\%$ & $\mathrm{n}$ & $\%$ \\
\hline $\begin{array}{l}\text { Telah melakukan vaksinasi } \\
\text { hepatitis B }\end{array}$ & 35 & 100,0 & 0 & 0,0 & 35 & 100,0 \\
\hline Menggunakan masker & 35 & 100,0 & 0 & 0,0 & 35 & 100,0 \\
\hline $\begin{array}{l}\text { Mencuci tangan sebelum } \\
\text { memakai sarung tangan }\end{array}$ & 30 & 8571 & 5 & 14.29 & 35 & 1000 \\
\hline Memakai sarung tangan & 35 & 100,0 & 0 & 0,0 & 35 & 100,0 \\
\hline $\begin{array}{l}\text { Memakai sarung tangan } \\
\text { bedah steril }\end{array}$ & 0 & 0,0 & 35 & 100,0 & 35 & 100,0 \\
\hline Memakai kacamata pelindung & 0 & 0,0 & 35 & 100,0 & 35 & 100,0 \\
\hline $\begin{array}{l}\text { Memakai pakaian } \\
\text { pelindung/baju kerja }\end{array}$ & 26 & 74,29 & 9 & 25,71 & 35 & 100,0 \\
\hline Memakai sepatu tertutup & 20 & 57,14 & 15 & 42,86 & 35 & 100,0 \\
\hline Rerata & & 64,64 & & 35,36 & & 100,0 \\
\hline
\end{tabular}


90 Jurnal e-Biomedik (eBm), Volume 7, Nomor 2, Juli-Desember 2019

Tabel 3. Perlindungan pribadi asisten operator sebelum tindakan ekstraksi gigi

\begin{tabular}{|c|c|c|c|c|c|c|}
\hline \multirow{2}{*}{ Perlindungan pribadi } & \multicolumn{2}{|c|}{ Ya } & \multicolumn{2}{|c|}{ Tidak } & \multicolumn{2}{|c|}{ Total } \\
\hline & $\mathrm{n}$ & $\%$ & $\mathrm{n}$ & $\%$ & $\mathrm{n}$ & $\%$ \\
\hline Telah melakukan vaksinasi & & & & & & \\
\hline hepatitis B & 35 & 100,0 & 0 & 0,0 & 35 & 100,0 \\
\hline Menggunakan masker & 35 & 100,0 & 0 & 0,0 & 35 & 100,0 \\
\hline Mencuci tangan sebelum & & & & & & \\
\hline memakai sarung tangan & 0 & 0,0 & 35 & 100,0 & 35 & 100,0 \\
\hline Memakai sarung tangan & 35 & 100,0 & 0 & 0,0 & 35 & 100,0 \\
\hline $\begin{array}{l}\text { Memakai sarung tangan bedah } \\
\text { steril }\end{array}$ & 0 & 0,0 & 35 & 100,0 & 35 & 100,0 \\
\hline Memakai kacamata pelindung & 0 & 0,0 & 35 & 100,0 & 35 & 100,0 \\
\hline $\begin{array}{l}\text { Memakai pakaian } \\
\text { pelindung/baju kerja }\end{array}$ & 0 & 0,0 & 35 & 100,0 & 35 & 100,0 \\
\hline Memakai sepatu tertutup & 13 & 37,14 & 22 & 62,86 & 35 & 100,0 \\
\hline Rerata & & 42,14 & & 57,86 & & 100,0 \\
\hline
\end{tabular}

Tabel 4. Pencegahan dan pengendalian infeksi silang sebelum tindakan ekstraksi gigi

\begin{tabular}{lccc}
\hline $\begin{array}{l}\text { Pencegahan dan pengendalian infeksi } \\
\text { silang sebelum tindakan ekstraksi gigi }\end{array}$ & $\begin{array}{c}\text { Ya } \\
\%\end{array}$ & $\begin{array}{c}\text { Tidak } \\
\%\end{array}$ & $\begin{array}{c}\text { Total } \\
\%\end{array}$ \\
\hline Desinfeksi lingkungan kerja operator & 31,43 & 68,57 & 100,0 \\
Perlindungan pribadi operator & 64,64 & 35,36 & 100,0 \\
Perlindungan pribadi asisten operator & 42,14 & 57,86 & 100,0 \\
Rerata & 46,07 & 53,93 & 100,0 \\
\hline
\end{tabular}

Tabel 5 menunjukkan 59,52\% responden melakukan tindakan pencegahan dan pengendalian infeksi silang selama

tindakan ekstraksi gigi, sedangkan 40,48\% responden tidak melakukannya.

Tabel 5. Pencegahan dan pengendalian infeksi silang selama tindakan ekstraksi gigi

\begin{tabular}{|c|c|c|c|c|c|c|}
\hline \multirow{2}{*}{$\begin{array}{c}\text { Tindakan pencegahan dan } \\
\text { pengendalian }\end{array}$} & \multicolumn{2}{|c|}{ Ya } & \multicolumn{2}{|c|}{ Tidak } & \multicolumn{2}{|c|}{ Total } \\
\hline & $\mathrm{n}$ & $\%$ & $\mathrm{n}$ & $\%$ & $\mathrm{n}$ & $\%$ \\
\hline $\begin{array}{l}\text { Pasien berkumur dengan larutan } \\
\text { antiseptik }\end{array}$ & 0 & 0,0 & 35 & 100,0 & 35 & 100,0 \\
\hline $\begin{array}{l}\text { Pengolesan desinfektan sebelum } \\
\text { insersi jarum suntik }\end{array}$ & 35 & 100,0 & 0 & 0,0 & 35 & 100,0 \\
\hline $\begin{array}{l}\text { Jarum suntik ditutup setelah } \\
\text { tindakan anastesi }\end{array}$ & 35 & 100,0 & 0 & 0,0 & 35 & 100,0 \\
\hline $\begin{array}{l}\text { Menutup jarum suntik dengan } \\
\text { teknik satu tangan }\end{array}$ & 0 & 0,0 & 35 & 100,0 & 35 & 100,0 \\
\hline $\begin{array}{l}\text { Meletakkan instrumen tajam yang } \\
\text { sudah terkontaminasi pada tempat } \\
\text { yang aman }\end{array}$ & 35 & 100,0 & 0 & 0,0 & 35 & 100,0 \\
\hline $\begin{array}{l}\text { Tangan operator tidak menyentuh } \\
\text { lingkungan kerja yang tidak steril }\end{array}$ & 20 & 57,14 & 15 & 42,86 & 35 & 100,0 \\
\hline Rerata & & 59,52 & & 40,48 & & 100,0 \\
\hline
\end{tabular}


Distribusi frekuensi pencegahan dan pengendalian infeksi silang setelah tindakan ekstraksi gigi terdiri dari operator dan asisten operator mencuci tangan setelah sarung tangan dibuka, asisten operator menggunakan sarung tangan yang terbuat dari bahan karet tebal sebelum mencuci instrumen, pemindahan baki instrumen dalam keadaan tertutup dan tidak melewati daerah steril, pembersihan instrumen, sterilisasi instrumen, penempatan sampah infeksius di wadah berwarna kuning, sampah instrumen tajam sekali pakai di safety box dan sampah non infeksius di wadah berwarna hitam. Tabel 6 menunjukkan $76,19 \%$ operator melakukan tindakan pencegahan dan pengendalian infeksi silang setelah tindakan ekstraksi gigi, sedangkan $23,81 \%$ operator tidak melakukannya.

Tabel 7 menunjukkan tindakan pencegahan dan pengendalian infeksi silang sebelum tindakan ekstraksi gigi, selama tindakan ekstraksi gigi dan setelah tindakan ekstraksi gigi.

Tabel 6. Pencegahan dan pengendalian infeksi silang setelah tindakan ekstraksi gigi

\begin{tabular}{|c|c|c|c|c|c|c|}
\hline \multirow{2}{*}{$\begin{array}{l}\text { Tindakan pencegahan dan } \\
\text { pengendalian }\end{array}$} & \multicolumn{2}{|c|}{ Ya } & \multicolumn{2}{|c|}{ Tidak } & \multicolumn{2}{|c|}{ Total } \\
\hline & $\mathrm{n}$ & $\%$ & $\mathrm{n}$ & $\%$ & $\mathrm{n}$ & $\%$ \\
\hline \multicolumn{7}{|l|}{$\begin{array}{l}\text { Mencuci tangan setelah sarung tangan } \\
\text { dibuka: }\end{array}$} \\
\hline Operator & 30 & 85,71 & 5 & 14,29 & 35 & 100,0 \\
\hline Asisten operator & 0 & 0,0 & 35 & 100,0 & 35 & 100,0 \\
\hline $\begin{array}{l}\text { Asisten operator menggunakan sarung } \\
\text { tangan karet tebal sebelum mencuci } \\
\text { instrumen bekas pakai }\end{array}$ & 0 & 0,0 & 35 & 100,0 & 35 & 100,0 \\
\hline $\begin{array}{l}\text { Pemindahan baki instrumen ke daerah } \\
\text { dekontaminasi dalam keadaan tertutup }\end{array}$ & 35 & 100,0 & 0 & 0,0 & 35 & 100,0 \\
\hline $\begin{array}{l}\text { Pemindahan instrumen terkontaminasi } \\
\text { tidak melewati daerah steril }\end{array}$ & 0 & 0,0 & 35 & 100,0 & 35 & 100,0 \\
\hline $\begin{array}{l}\text { Pembersihan instrumen bekas pakai } \\
\text { dengan air,sikat dan deterjen }\end{array}$ & 35 & 100,0 & 0 & 0,0 & 35 & 100,0 \\
\hline Sterilisasi instrumen & 35 & 100,0 & 0 & 0,0 & 35 & 100,0 \\
\hline $\begin{array}{l}\text { Menempatkan sampah infeksius pada } \\
\text { tempat sampah berwarna kuning }\end{array}$ & 35 & 100,0 & 0 & 0,0 & 35 & 100,0 \\
\hline $\begin{array}{l}\text { Menempatkan jarum suntik dan } \\
\text { instrumen tajam sekali pakai pada } \\
\text { safety box yang tahan bocor }\end{array}$ & 35 & 100,0 & 0 & 0,0 & 35 & 100,0 \\
\hline $\begin{array}{l}\text { Menempatkan sampah non infeksius di } \\
\text { tempat sampah berwarna hitam }\end{array}$ & 35 & 100,0 & 0 & 0,0 & 35 & 100,0 \\
\hline Rerata & & 76,19 & & 23.81 & & 100,0 \\
\hline
\end{tabular}

Tabel 7. Pencegahan dan pengendalian infeksi silang sebelum, selama dan setelah tindakan ekstraksi gigi

\begin{tabular}{lccc}
\hline \multicolumn{1}{c}{$\begin{array}{c}\text { Pencegahan dan pengendalian } \\
\text { infeksi silang }\end{array}$} & $\begin{array}{c}\text { Ya } \\
\%\end{array}$ & $\begin{array}{c}\text { Tidak } \\
\%\end{array}$ & $\begin{array}{c}\text { Total } \\
\%\end{array}$ \\
\hline Sebelum tindakan ekstraksi gigi & 46,07 & 53,93 & 100,0 \\
Selama tindakan ekstraksi gigi & 59,52 & 40,48 & 100,0 \\
Setelah tindakan ekstraksi gigi & 76,19 & 23,81 & 100,0 \\
Rerata & 60,59 & 39,41 & 100,0 \\
\hline
\end{tabular}




\section{BAHASAN}

Pada penelitian ini, tindakan ekstraksi gigi yang diteliti sebanyak 35 tindakan yang terbagi atas pencegahan dan pengendalian infeksi silang sebelum tindakan ekstraksi gigi, selama tindakan ekstraksi gigi dan setelah tindakan ekstraksi gigi.

Pencegahan dan pengendalian infeksi silang sebelum tindakan ekstraksi gigi terdiri dari tindakan desinfeksi permukaan kerja, perlindungan pribadi operator dan perlindungan pribadi asisten operator. Tabel 1 menunjukkan hanya sebesar $31,43 \%$ responden yang melakukan tindakan desinfeksi lingkungan kerjanya.. Berdasarkan pengamatan penulis, tindakan desinfeksi area kerja responden hanya dilakukan setiap pagi hari pada awal poli gigi memulai jam operasional pelayanan dan tidak dilakukan setiap pergantian pasien. Area kerja responden seperti pegangan lampu, tombol dental unit, sandaran kepala pasien, tempat duduk dan meja instrumen dilakukan tindakan desinfeksi dengan menggunakan kain lap yang dibasahi dengan cairan desinfektan berupa alkohol $70 \%$. Apabila terdapat percikan darah atau saliva dari pasien di area kerja, responden biasanya menggunakan tisu basah terlebih dahulu untuk menghilangkan sisa darah dan saliva pasien tersebut sebelum mengguna-kan kain lap yang dibasahi dengan alkohol 70\%. Berdasarkan hasil tanya jawab dengan responden, diperoleh alasan mengapa tindakan desinfeksi area kerja hanya dilakukan di pagi hari ketika awal jam operasional poli gigi dilakukan. Responden beralasan apabila tindakan desinfeksi area kerja dilakukan setiap pergantian pasien akan menyita waktu yang cukup banyak dan membuat waktu perawatan setiap pasien akan bertambah. Selain itu menurut responden tindakan desinfeksi area kerja operator hanya perlu dilakukan ketika area kerja operator benar-benar terpapar darah atau saliva pasien. Hal ini menunjukkan masih kurangnya pemahaman dan kesadaran responden akan bahaya infeksi silang ketika melakukan tindakan ekstraksi gigi di area kerja operator yang tidak dilakukan tindakan desinfeksi terlebih dahulu. Adanya percikan saliva bercampur darah pada lingkungan kerja responden yang terkadang tidak tampak dengan mata telanjang sangat berpotensi menyebabkan terjadinya penyebaran infeksi melalui infeksi silang antara pasien ke operator atau ke tenaga kesehatan yang bertugas di rumah sakit serta ke masyarakat pengunjung rumah sakit.

Selanjutnya hasil penelitian perlindungan pribadi operator sebelum tindakan ekstraksi gigi menunjukkan $64,64 \%$ responden telah melakukan tindakan perlindungan pribadi (Tabel 2). Tindakan perlindungan pribadi ini meliputi vaksinasi hepatitis $B$ dan penggunaan alat pelindung diri (APD). Semua responden, yakni operator $(100 \%)$ telah melakukan vaksinasi hepatitis B. Hal ini tentunya menunjukkan adanya kesadaran responden akan pentingnya vaksinasi hepatitis B untuk menghindari risiko infeksi silang saat melakukan tindakan ekstraksi gigi.

Hasil penelitian mengenai perlindungan pribadi berupa mencuci tangan sebelum menggunakan sarung tangan, terdapat $85,71 \%$ responden melakukan tindakan tersebut. Hasil ini sejalan dengan penelitian yang dilakukan oleh Siampa ${ }^{7}$ di Makassar mengenai dokter gigi mencuci tangan sebelum menggunakan sarung tangan, yang mendapatkan hasil yang hampir sama yaitu sebesar 86,00\% responden yang melakukannya. Idealnya semua responden harus melakukan tindakan mencuci tangan sebelum memakai sarung tangan mengingat pentingnya tindakan ini untuk menghilangkan kotoran dan debu secara mekanis dari permukaan kulit dan mengurangi jumlah mikroorgnaisme yang menempel di tangan.

Dalam hal penggunaan sarung tangan semua responden $(100 \%)$ sudah menggunakannya. Hasil ini menunjukkan kesadaran responden akan pentingnya penggunaan alat perlindungan diri berupa sarung tangan sudah baik. Namun berdasarkan pengamatan penulis, sarung tangan yang digunakan belum sesuai dengan peruntukan tindakan ekstraksi gigi yang akan dilakukan 
responden. Sarung tangan yang digunakan responden ialah sarung tangan periksa yang terbuat dari bahan vinil yang tipis dan mudah sobek. Penggunaan sarung tangan ini saat melakukan tindakan ekstraksi gigi akan meningkatkan risiko terjadinya infeksi silang karena mudah sobek ketika tertusuk instrumen tajam yang sudah terkontaminasi. Dengan demikian meningkatkan risiko penularan infeksi dari pasien ke operator. Seharusnya responden menggunakan jenis sarung tangan bedah (sarung tangan latex) yang sesuai peruntukannya untuk tindakan ekstraksi gigi karena steril dan tidak mudah sobek.

Hasil penelitian menunjukkan semua (100\%) respoden menggunakan masker saat akan melakukan tindakan ekstraksi gigi. Hasil penelitian ini didukung oleh penelitian sebelumnya tentang proteksi dokter gigi sebagai pemutus rantai infeksi silang yang dilakukan oleh Wibowo et $\mathrm{al}^{8}$ di Makassar, yang melaporkan sebagian besar dokter gigi $(82,5 \%)$ menggunakan masker setiap memeriksa pasien. Namun berdasarkan pengamatan penulis, masker yang digunakan responden tidak diganti setiap pergantian pasien. Masker yang tidak diganti setiap pergantian pasien dapat menjadi media penularan infeksi silang karena terkena cipratan darah ataupun saliva dari pasien sebelumnya.

Hasil penelitian tentang penggunaan kacamata pelindung menujukkan semua respoden tidak menggunakan kacamata pelindung sebelum melakukan tindakan ekstraksi gigi. Berdasarkan hasil tanya jawab, respoden umumnya sudah memahami pentingnya penggunaan kacamata pelindung untuk menghindari terpaparnya selaput lendir mata terhadap percikan darah atau saliva pasien, namun responden menganggap penggunaan kacamata pelindung saat bekerja mengganggu kenyamanan saat bekerja. Selain itu tidak disediakannya kacamata pelindung oleh pihak Rumah Sakit Pancaran Kasih di Poliklinik Gigi membuat responden terbiasa tidak menggunakan kacamata pelindung saat melakukan tindakan ekstraksi gigi. Hal ini juga dijelaskan dan serupa dengan penelitian
Wibowo et al $^{8}$ yang mendapatkan $37,5 \%$ responden yang menggunakan kacamata pelindung dikarenakan responden merasa kurang nyaman dalam menggunakannya saat melakukan tindakan ekstraksi gigi.

Hasil penelitian tentang pemakaian pakaian pelindung atau baju kerja yang bersih mendapatkan $74,29 \%$ responden menggunakannya. Pakaian pelindung yang digunakan berupa snelli atau jas dokter bertangan pendek. Namun dari pengamatan penulis masih ada responden yang tidak menggunakannya. Berdasarkan hasil tanya jawab, respoden beralasan menggunakan pakaian pelindung/jas kerja mengganggu kenyamanan saat bekerja. Selain itu responden tidak mengetahui apakah ada ketentuan dari pihak rumah sakit Pancaran Kasih yang mewajibkan penggunaan pakaian pelindung/jas kerja saat bekerja. Hal ini menunjukkan masih kurangnya pemahaman sebagian operator akan pentingnya penggunaan pakaian pelindung saat menangani pasien, dalam hal ini pada tindakan ekstraksi gigi. Kurangnya pengawasan dari pihak rumah sakit juga menyebabkan beberapa responden tidak menggunakan pakaian pelindung/jas kerja saat menangani pasien.

Mengenai penggunaan alat perlindungan diri berupa penggunaan sepatu tertutup didapatkan hasil $57,14 \%$ responden sudah menggunakannya. Pemakaian sepatu tertutup sendiri bertujuan untuk menghindari cederanya kaki operator dari instrumen bekas pakai yang terjatuh dan melukai operator. Berdasarkan hasil tanya jawab, responden sebenarnya sadar akan pentingnya penggunaan sepatu tertutup untuk menghindari bahaya terjadinya infeksi silang, namun karena tidak adanya aturan yang mewajibkan penggunaannya dan kurangnya pengawasan dari pihak rumah sakit membuat responden memilih untuk tidak menggunakannya. Alasan yang dikemukakan menunjukkan masih kurangnya pemahaman operator akan bahaya infeksi silang yang mungkin terjadi akibat tidak digunakannya pakaian pelindung.

Penelitian mengenai perlindungan pribadi asisten operator menunjukkan hasil 
$42,14 \%$ responden telah melakukan tindakan perlindungan pribadi (Tabel 3). Semua asisten operator $(100 \%)$ telak melakukan vaksinasi hepatitis B yang menunjukkan adanya kesadaran responden akan bahaya resiko infeksi silang apabila tidak melakukan vaksinasi hepatitis B. Selanjutnya bentuk perlindungan pribadi berupa mencuci tangan sebelum memakai sarung tangan, menunjukkan tidak ada satupun (0\%) responden yang melakukannya. Berdasarkan hasil tanya jawab, responden beralasan pada saat tindakan ekstraksi gigi responden tidak akan bersentuhan langsung dengan mukosa mulut pasien sehingga tidak perlu melakukan cuci tangan sebelum menggunakan sarung tangan. Hal ini menunjukkan masih kurangnya pemahaman dan kesadaran responden akan pentingnya mencuci tangan sebelum menggunakan sarung tangan. Tindakan cuci tangan dapat mengurangi mikroorganisme yang terdapat di tangan dan dapat mencegah tangan menjadi media penularan infeksi silang karena mungkin saja responden sebelum menggunakan sarung tangan telah menyentuh permukaan kerja yang tidak didesinfeksi terlebih dahulu. Selanjutnya dalam hal penggunaan sarung tangan, didapatkan hasil semua responden (100\%) menggunakan sarung tangan sebelum tindakan ekstraksi gigi dilakukan. Namun sayangnya sarung tangan yang digunakan hanya merupakan sarung tangan periksa yang tidak sesuai dengan tindakan yang akan dilakukan oleh responden. Berdasarkan hasil tanya jawab, responden merasa tidak perlu menggunakan sarung tangan bedah steril pada saat sebelum melakukan tindakan ekstraksi gigi, karena tidak akan bersentuhan langsung dengan mukosa mulut pasien pada saat tindakan ekstraksi gigi. Hal ini menunjukkan masih kurangnya pemahaman responden akan bahaya infeksi silang yang tidak hanya dapat terjadi melalui kontak langsung dengan pasien, namun juga dapat terjadi dengan cara kontak tidak langsung, salah satunya melalui instrumen bekas pakai yang akan bersentuhan langsung dengan tangan saat melakukan tindakan ekstraksi gigi.
Dalam hal pemakaian baju pelindung dan kacamata pelindung, didapatkan hasil tidak ada $(0 \%)$ responden yang menggunakannya. Responden beralasan tidak disediakannya baju kerja dan kacamata pelindung dari pihak Rumah Sakit Pancaran Kasih Manado membuat mereka merasa tidak perlu menggunakannya. Selain itu responden beralasan menggunakan baju kerja dan kacamata pelindung dapat mengurangi kenyamanan saat bekerja. Menurut penulis, responden belum memahami pentingnya penggunaan baju kerja dan kacamata pelindung sebagai alat perlindungan diri untuk menghindari percikan darah dan saliva pasien yang dapat menjadi media penularan infeksi silang saat membantu operator ketika tindakan ekstraksi gigi dilakukan.

Hasil penelitian penggunaan alat perlindungan diri berikutnya berupa penggunaan sepatu tertutup saat tindakan ekstraksi gigi menunjukkan hasil yang rendah yaitu $37,14 \%$ responden yang menggunakan sepatu tertutup. Penggunaan sepatu tertutup sendiri bertujuan untuk menghindari tertusuknya kaki ketika ada instrumen yang terjatuh pada saat tindakan ekstraksi gigi sedang dilakukan. Berdasarkan hasil tanya jawab, responden beralasan menggunakan sepatu tertutup membuat kenyamanan saat bekerja berkurang. Hal ini menandakan masih kurangnya pemahaman responden akan bahaya tertusuk instrumen bekas pakai apabila tidak menggunakan sepatu tertutup. Selain itu, kurangnya pengawasan dari pihak rumah sakit membuat tindakan ini seringkali diabaikan oleh responden.

Hasil penelitian mengenai tindakan pencegahan dan pengendalian infeksi silang sebelum tindakan ekstraksi gigi dilakukan sebesar rata-rata 46,07\% (Tabel 4). Hasil ini menunjukkan bahwa tindakan pencegahan dan pengendalian infeksi silang sebelum tindakan ekstraksi gigi hanya dilakukan sebagian kecil responden. Kondisi ini menunjukkan masih kurangnya pengetahuan responden yang mengakibatkan belum maksimalnya upaya yang dilakukan responden untuk mengurangi 
resiko terjadinya infeksi silang dengan cara penggunaan alat perlindungan diri sebelum melakukan tindakan ekstraksi gigi.

Pencegahan dan pengendalian infeksi silang selama tindakan ekstraksi gigi meliputi tindakan asepsis pada pasien, pencegahan kecelakaan kerja dan pencegahan penularan infeksi melalui operator. Hasil penelitian ini mendapatkan rerata $59,52 \%$ responden yang melakukan tindakan pencegahan infeksi silang selama tindakan ekstraksi gigi (Tabel 5). Hasil ini menandakan bahwa tingkat kesadaran dan kewasapadaan responden mengenai bahaya infeksi silang saat sedang melakukan tindakan ekstraksi gigi belum maksimal. Dari hasil penelitian, apabila diperhatikan lebih lanjut terdapat salah satu tindakan yang sama sekali tidak dilakukan responden, yaitu tindakan asepsis pada pasien berupa berkumur dengan larutan antiseptik. Hasil ini sebanding dengan penelitian yang dilakukan Ramadhani et $\mathrm{al}^{9}$ mengenai tindakan pencegahan dan pengendalian infeksi pada perawatan periodonsia. Pada penelitian tersebut didapatkan hasil tidak ada responden yang menginstruksikan pasien berkumur dengan larutan antiseptik. Berkumur dengan larutan antiseptik bertujuan untuk mengurangi jumlah mikroba di mulut sesaat sebelum melakukan tindakan ekstraksi gigi. Dari pengamatan penulis, responden hanya menyuruh pasien berkumur-kumur dengan air mineral sesaat sebelum tindakan ekstraksi gigi dilakukan. Berdasarkan hasil tanya jawab dengan responden didapatkan keterangan bahwa tidak tersedianya larutan berkumur antiseptik di Poliklinik Gigi Rumah Sakit Pancaran Kasih membuat responden memilih tidak melakukan tindakan ini.

Selanjutnya untuk tindakan pemberian desinfektan sebelum insersi jarum suntik sudah dilakukan oleh semua (100\%) responden dengan menggunakan larutan povidon iodine yang dioles menggunakan cotton pellet pada daerah kerja di rongga mulut yang akan menjadi tempat insersi jarum suntik.

Tindakan pencegahan kecelakaan ker- ja, yaitu menutup jarum suntik setelah tindakan anastesi sudah dilakukan oleh semua (100\%) responden. Namun yang patut diperhatikan, tindakan menutup jarum suntik yang dilakukan semua (100\%) responden belum menggunakan teknik satu tangan. Menutup jarum suntik dengan teknik satu tangan sendiri bertujuan untuk menghindari tertusuknya jarum suntik ke tangan responden secara tidak disengaja. Hal ini menandakan masih kurangnya pengetahuan responden akan bahaya jarum suntik bekas pakai yang dapat menjadi media penularan infeksi silang apabila secara tidak sengaja tertusuk di tangan responden. Kurangnya pengetahuan responden menyebabkan responden kurang waspada akan bahaya infeksi yang dapat menular melalui jarum suntik bekas yang sudah terkontaminasi diantaranya ialah infeksi virus Hepatitis B dan HIV.

Hasil penelitian untuk upaya menghindari tertusuknya instrumen tajam bekas pakai dengan meletakkannya di tempat yang aman sudah dilakukan oleh semua (100\%) responden. Dari pengamatan penulis, pada saat sedang melakukan tindakan ekstraksi gigi, responden akan menempatkan instrumen tajam yang telah selesai digunakan di baki terpisah sehingga dapat menghindari bahaya tertusuk instrumen tajam bekas pakai tersebut.

Hasil penelitian mengenai tindakan pencegahan penularan infeksi melalui responden (operator) yaitu tangan responden tidak menyentuh lingkungan kerja yang tidak steril, didapatkan hasil 57,14\% responden melakukannya. Berdasarkan pengamatan penulis, saat sedang melakukan tindakan ekstraksi gigi tangan responden masih sering menyentuh area-area tidak steril seperti tombol-tombol dental unit ataupun mengatur posisi lampu pencahayaan dental unit. Responden seringkali tidak memanfaatkan tenaga asisten operator yang ada untuk membantu responden bekerja sehingga dapat fokus melakukan tindakan ekstraksi gigi saja. Hal ini tentunya dapat meningkatkan resiko terjadinya infeksi silang kepada pasien karena tangan responden yang melakukan 
tindakan ekstraksi gigi sudah tidak steril lagi karena sebelumnya sudah menyentuh area-area yang tidak steril.

Pencegahan dan pengendalian infeksi silang setelah tindakan ekstraksi gigi terdiri dari perlindungan pribadi, penanganan instrumen bekas pakai dan penanganan sampah medis. Hasil pengamatan mengenai perlindungan pribadi operator dan asisten operator yaitu mencuci tangan setelah sarung tangan dibuka, didapatkan hasil rata-rata $85,71 \%$ untuk operator dan tidak ada satupun asisten operator (0\%) yang melakukannya. Dari pengamatan penulis, setelah tindakan ekstraksi gigi dilakukan asisten operator akan segera melakukan tindakan mencuci instrumen bekas pakai tanpa melepas sarung tangan. Proses pencucian instrumen bekas pakai ini sendiri dilakukan asisten operator tanpa menggunakan sarung karet tebal. Hal ini sebanding dengan penelitian yang dilakukan oleh Ramadhani et $\mathrm{al}^{9}$ mengenai tindakan pencegahan dan pengendalian infeksi silang pada perawatan periodonsia. Pada penelitian tersebut didapatkan hasil tidak ada responden yang menggunakan sarung tangan karet tebal pada saat mencuci instrumen bekas pakai. Berdasarkan hasil tanya jawab dengan responden, responden beralasan tidak tersedianya sarung tangan karet tebal untuk digunakan sebelum mencuci instrumen bekas pakai membuat responden lebih memilih menggunakan sarung tangan yang dipakai saat tindakan ekstraksi gigi untuk mencuci instrumen bekas pakai. Hal ini tentunya berbahaya karena sarung tangan yang digunakan ialah sarung tangan periksa yang tipis dan mudah sobek sehingga meningkatkan isiko terjadinya infeksi silang melalui luka tusukan instrumen bekas pakai pada saat penggunaanya dalam mencuci instrumen bekas pakai.

Pada penanganan instrumen bekas pakai, yaitu pemindahan baki instrumen dari daerah kerja ke daerah dekontaminasi dalam keadaan tertutup sudah dilakukan oleh semua (100\%) responden. Asisten operator akan membawa baki instrumen bekas pakai dalam keadaan tertutup ke tempat penyucian alat untuk dilakukan dekontaminasi pada instrumen bekas pakai. Selanjutnya hasil penelitian mengenai pemindahan instrumen yang terkontaminasi tidak melewati daerah yang steril tidak dilakukan oleh semua (100\%) responden. Berdasarkan pengamatan penulis di Rumah Sakit Pancaran Kasih Manado tidak ditentukan alur akses atau jalur pemindahaan instrumen yang terkontaminasi sehingga responden ketika melakukan pemindahan instrumen yang terkontaminasi bebas lalu-lalang di satu jalur saja. Hal ini tentunya dapat meningkatkan risiko terjadinya infeksi silang yang berasal dari kontak dengan alat/instrumen yang sudah terkontaminasi darah dan saliva pasien ke asisten operator, tenaga kesehatan lain atau pengunjung yang lalu lalang di rumah sakit.

Hasil penelitian untuk pembersihan instrumen bekas pakai dengan air, sikat dan deterjen sudah dilakukan oleh semua $(100 \%)$ responden. Hal ini menandakan responden sudah memahami pentingnya hal tersebut untuk dilakukan sebagai salah satu upaya pencegahan dan pengendalian infeksi silang setelah tindakan ekstraksi gigi.

Selanjutnya dalam hal penanganan sampah medis yang terbagi atas sampah infeksius, sampah jarum suntik atau instrumen tajam bekas pakai dan sampah non infeksisus, menunjukkan hasil semua responden $(100 \%)$ sudah menempatkan sampah-sampah tersebut pada tempat sampah sesuai dengan jenisnya. Namun yang perlu menjadi perhatian untuk tempat sampah infeksius dan non infeksius hanyalah tempat sampah berwarna sama yang diberi label berbeda yaitu tempat sampah infeksius dan non infeksius sebagai pembeda. Menurut pendapat penulis, tempat sampah infeksius dan non infeksius sebaiknya diganti dengan tempat sampah yang berbeda warna yaitu warna kuning untuk sampah infeksius dan warna hitam untuk sampah non infeksius untuk lebih memudahkan operator ketika akan membuang kedua jenis sampah tersebut.

Secara umum hasil penelitian menunjukkan rerata $76,19 \%$ responden melakukan tindakan pencegahan dan pengendalian 
infeksi silang setelah tindakan ekstraksi gigi (Tabel 6). Hasil yang diperoleh menunjukkan belum maksimalnya pelaksanaan tindakan pencegahan dan pengendalian infeksi silang setelah tindakan ekstraksi gigi.

\section{SIMPULAN}

Berdasarkan hasil penelitian ini dapat disimpulkan bahwa pencegahan dan pengendalian infeksi silang pada tindakan ekstraksi gigi di Poliklinik Gigi Rumah Sakit Pancaran Kasih Manado secara umum belum maksimal.

Bagi institusi terkait, diharapkan meyelenggarakan kegiatan-kegiatan pelatihan atau seminar untuk meningkatkan pengetahuan tenaga kesehatan gigi mengenai tindakan pencegahan dan pengendalian infeksi. Institusi rumah sakit wajib menyiapkan standar prosedur operasional untuk tindakan pencegahan dan pengendalian infeksi di rumah sakit termasuk di poliklinik gigi disertai pengawasan dan evaluasi yang ketat guna memberikan pelayanan kesehatan yang bermutu bagi masyarakat. Tenaga kesehatan gigi dan penyedia pelayanan kesehatan gigi agar lebih mengoptimalkan tindakan pencegahan dan pengendalian infeksi silang untuk meningkatkan mutu pelayanan kesehatan.

\section{DAFTAR PUSTAKA}

1. Paparang FS, Rampengan S. Analisis penerapan pencegahan dan pengen- dalian infeksi di poli gigi Rumah Sakit Umum Daerah Tobelo Kabupaten Halmahera Utara. Jurnal Kesehatan. 2017;2(4):3-5

2. Kementerian Kesehatan Republik Indonesia.

Riset Kesehatan Dasar Nasional (Riskesdas) 2013. Jakarta, 2013; p. 8-9.

3. Kementerian Kesehatan Republik Indonesia. Standar pencegahan dan pengendalian infeksi pelayanan kesehatan gigi dan mulut di fasilitas pelayanan kesehatan. Jakarta, 2013; p. 12-36.

4. Dinas Kesehatan Provinsi Sulawesi Utara. Profil kesehatan provinsi sulawesi utara 2016. Manado, 2016; p. 64-5.

5. Wheeler M, Castellsague $X$. Cross infection type, causes and prevention. Lancet. 2008;13(1):100-10

6. Epidemiology of nosocomial infections. In: Ducel G, Fabry J, Nicolle L, editors. Prevention of Hospital Acquired Infections, A Practical Guide (2nd ed). Malta: World Health Organization, 2015; p. 4-8.

7. Siampa A. Penerapan proteksi dokter gigi sebagai upaya pencegahan terhadap infeksi silang [Skripsi]. Makassar: Fakultas Kedokteeran Gigi Universitas Hasanuddin; 2015.

8. Wibowo T, Parihsihni K, Haryanto D. Proteksi dokter gigi sebagai pemutus rantai infeksi silang. Jurnal PDGI. 2009;58(2):6-9.

9. Ramadhani WR, Kepel BJ, Parengkuan WG. Tindakan pencegahan dan pengendalian infeksi pada perawatan periodonsia di RSGM PSPDG FK Unsrat. eG. 2015;3(2):409-15. 